\title{
DOES THE PACKAGING CHANGE THE PERCEIVED TASTE OF BEER? RESULTS FROM A BEER EXPERIMENT
}

\section{MIJENJA LI AMBALAŽA PERCIPIRANI OKUS PIVA? REZULTATI EKSPERIMENTA S PIVOM}

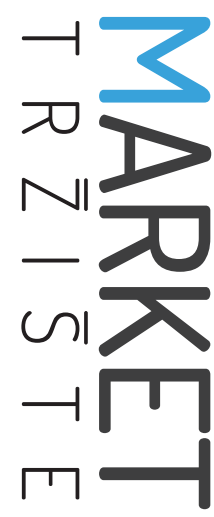

\author{
Market-Tržište \\ Vol. 32, No. 1, 2020, pp. 65-78 \\ UDK 005.6:007:364.32(594) \\ DOl http://dx.doi.org/10.22598/mt/2020.32.1.65 \\ Preliminary communication
}

\begin{abstract}
Jan Zavodny Pospisila, Lucie Sara Zavodna ${ }^{b}$, Matej Jiranek ${ }^{c}$
a University of Economics - Prague, Faculty of Management, Jarosovska 1117/II, 37701 Jindrichuv Hradec, CZECH REPUBLIC, e-mail: jan.zavodny@vse.cz

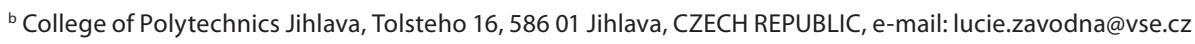

c University of Economics - Prague, Faculty of Management, Jarosovska 1117/II, 37701 Jindrichuv Hradec, CZECH REPUBLIC, e-mail: jirm11@vse.cz
\end{abstract}

\begin{abstract}
Purpose - The purpose of this research was to verify actual consumer behavior concerning different beer packaging material and how it influences the perception of beer taste. More precisely, the main aim of the paper was to explore whether beer packaging can influence consumers' subjectively perceived taste of the beer they drink.
\end{abstract}

Design/Methodology/Approach - Following the literature research, a questionnaire survey was conducted on a sample of average Czech beer consumers $(n=220)$. A subsequent experiment involving a sample of Czech college students $(n=30)$ aimed at exploring the actual consumer behavior.

Findings and implications - The results of the experiment show that beer consumer behavior can be influenced by the beer packaging material. If consumers knew that the beer had been poured from a glass bottle, they assessed its taste better than if they had no information on the type of beer packaging. Similarly, the opposite was found to be true of the plastic bottle - if consumers knew that the beer had been poured from a plastic bottle, they said it tasted worse than if they had

\section{Sažetak}

Svrha - Svrha istraživanja bila je provjeriti ponašanje potrošača ovisno o različitim vrstama ambalaže piva te kako ona utječe na percepciju okusa piva. Preciznije, glavni cilj rada bio je otkriti može li ambalaža piva utjecati na potrošačevu subjektivnu percepciju njegova okusa.

Metodološki pristup - Nakon pregleda literature provedeno je anketiranje na uzorku prosječnih čeških potrošača piva $(n=220)$. Kako bi se otkrilo stvarno ponašanje potrošača, proveden je eksperiment na uzroku čeških studenata $(n=30)$.

Rezultati i implikacije - Rezultati eksperimenta pokazuju da ambalaža može utjecati na ponašanje potrošača piva. U situaciji kada su potrošači znali da je pivo točeno iz staklene boce, ocijenili su ga ukusnijim u odnosu na situaciju kada nisu imali informaciju o ambalaži piva, odnosno obratno vrijedi za plastične boce. Kada su potrošači znali da je pivo iz plastične boce, ocijenili su da ima lošiji okus nego kad nisu imali tu informaciju. Nisu pronađene statistički značajne razlike u degustaciji piva iz limenke u odnosu na (ne)posjedovanje informacije o vrsti ambalaže. 
no such information. No statistically significant difference was found in the tasting of canned beer with or without the knowledge of the packaging material.

Limitation - The main research limitations lie in its regionality as the survey and the experiment were conducted only in the Czech Republic, with college students as participants.

Originality - As there is only a limited amount of research available on beer packaging and its influence on consumer behavior, this paper provides a valuable overview of the issue.

Keywords - consumer, packaging, beer, consumption, preferences, students
Ograničenja - Glavna ograničenja istraživanja vezana su uz regionalnost, jer su istraživanje i eksperiment provedeni samo u Republici Češkoj, te činjenicu da su sudionici eksperimenta bili studenti.

Doprinos - S obzirom na postojanje ograničenoga broja istraživanja o ambalaži piva i utjecaju na ponašanje potrošača, rad pruža vrijedan pregled problematike.

Ključne riječi - potrošač, ambalaža, pivo, konzumacija, preferencije, studenti 


\section{INTRODUCTION}

In casual conversation, Czech consumers often say that in case of packaged beers, the beer from a glass bottle tastes better than that served in a can or plastic bottle (e.g., Petr, 2018). This is a peculiar phenomenon, considering that the beer is still the same. However, such statements can have scientific explanations as numerous studies highlight the influence of the different amounts of oxygen on the taste of the beer (e.g., Lorencová, Salek, Černošková \& Buňka, 2019; Baxter, Hornsey \& Hughes, 2001; Kuchel, Brody \& Wicker, 2006), while other claim that the packaging taints the contents (e.g., Andrés-Iglesias et al., 2016; Vesely, Lusk, Basarova, Seabrooks \& Ryder, 2003), or that there could be a reaction between the packaging material and the beer (e.g., Vaughan, O'Sullivan \& Sinderen, 2005; Burns, Heyerick, De Keukeleire \& Forbes, 2001). However, in an imaginary situation in which a consumer is offered a glass of beer poured from unknown packaging material and assuming that they prefer beer from a glass bottle, would they be able to recognize when it is poured from a can or plastic bottle?

It is well-known that the packaging has a significant psychological effect on the consumer perception of a product, which also includes beer (e.g., Aquilani, Laureti, Poponi \& Secondi, 2015; Velasco, Woods, Petit, Cheok \& Spence, 2016; Spence \& Piqueras-Fiszman, 2012). In this regard, Barnett, Velasco and Spence (2016) point out that packaging preference and related taste perception can also be caused by the historical role and image of certain packaging. In this sense, beer packaging preferences and related taste perceptions in Czech consumers could be influenced by the historical familiarity of the different beer packaging. If this is the case, then the perceived packaging-taste relation should be: (1) glass bottle, (2) can, and (3) plastic bottles, as this complies with the timeline that individual beer packaging was launched on the Czech market. From the marketing point of view, it is essential to know (1) the reasons why consumers prefer some packaging materials over oth- ers, while from the scientific point of view, it is vital to determine (2) whether the packaging material has any impact on the perceived beer taste. As part of this research study, a survey was administered in the Czech Republic on a wide range of beer consumers. In addition, to be able to explore the second issue mentioned, an experiment involving a specific target group of students was conducted.

\section{THEORETICAL BACKGROUND AND RESEARCH QUESTION DEVELOPMENT}

The brewing industry has been prevalent in the Czech Republic for centuries and has become a traditional and economically significant Czech industry (Rumánková, Šánová \& Kolář, 2019). The overall beer consumption among Czech consumers is extremely high and has historically been even higher (Van Herck, Swinnen \& Deconinck, 2012). Every year, the Czech Republic ranks among the global leaders in beer consumption per person and has ranked in the top position several times (Castiglione, Grochová, Infante \& Smirnova, 2011). Owing to this high level of beer consumption, the Czech Republic is sometimes even ranked among the so-called "drinking nations" (Swinnen, 2011). The annual consumption of beer is around 138 liters per person, which equals approximately 276 Czech pints of beer (Vacl, 2018). No one should be surprised that the beer culture in the Czech Republic is as traditional as the wine culture in France (Foret \& Procházka, 2012). Thus, the Czech beer market is particularly important and has great potential (Rumánkova et al., 2019). Its significance is also proven by the number of tourists who appreciate the country's beer, along with its tourist attractions during their visits (Kotíková, 2013). In recent years, as in some other countries too, there has been a significant development at the level of small and medium-sized enterprises (SME) in the area of small breweries, which are highly popular with consumers (Vacl, 2018). 


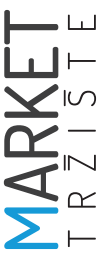

Whether from the perspective of large corporations, SMEs, or consumers themselves, the beer market and beer culture are of great importance to the Czech Republic.

Although overall beer consumption in the Czech Republic is high, there has been a downward trend in consumption. Kozák (2013) noted that, over the past 20 years, beer consumption had decreased by $20 \%$. This can be due to many reasons, such as the changes in the buying behavior of the younger generation, who are the consumption majority nowadays (Brager \& Greco, 2011). The so-called "Millennials" differ in the way they consume alcoholic beverages, including beer (Aquilani et al., 2015). They pay more attention to the nutritional components and health benefits associated with moderate beer consumption (Sohrabvandi, Mortazavian \& Rezaei, 2012). A fact particularly significant for breweries is that the changes in beer consumption patterns have led younger consumers to different types of products; they are now mostly focused on craft beers (Aquilani et al., 2015), which is believed to result from the so-called "taste revolution" (Kleban \& Nickerson, 2012).

European breweries have addressed these changes in different ways. Some have tried to enhance their marketing communication activities (Kozák, 2013), while others have improved their brand (Kotler, Armstrong, Saunders \& Wong, 2005), and others still have financially invested in small breweries (Smith, Farrish, McCarroll \& Huseman, 2017). Overall, the most important issue is to understand the main consumer segment. When it comes to the future, attention should be focused on prospective consumers - young people.

In the Czech Republic, the legal age limit for alcohol is 18 years old, which means that Czech students can consume alcoholic beverages. According to the surveys such as those conducted by Bräker and Soellner (2016), many of them start drinking much earlier than this age limit. Students are thus relatively experienced consumers at an early age. Moreover, their early preferences for alcohol drink consumption may affect their future preferences (Lintonen \& Konu, 2003).

Leaving ethical and health problems aside, it could be said that students are a crucial market segment for brewery marketing experts (Kuo, Wechsler, Greenberg \& Lee, 2003); similar to selling cigarettes to teenagers, a habit that companies will use in the future is being created. Therefore, understanding the formation of students' needs and wishes is crucial to marketeers.

To this extent, the total alcohol consumption in the Czech Republic does not change (Kozák, 2013). The Millennials' consumption styles may only be a fad (Aquilani et al., 2015); they still drink beer, only the brand or manufacturer has changed. Thus, there is a common beer consumption that is affected by different factors. As stated by Aquilani et al. (2015), two categories of factors can be distinguished: (1) beer attributes such as aroma, carbonation, foam, etc. and (2) factors related to the purchase process. The purchase-related factors are well-described in the literature because they are similar to almost all products (Kotler et al., 2005). In this sense, the following factors can be recognized in connection with beer: (a) price (Rojas \& Shi, 2011; Lopez \& Matschke, 2012), (b) brand (Bronnenberg, Dubé \& Gentzkow, 2012; Galizzi \& Garavaglia, 2012), (c) distribution (Aquilani et al., 2015), (d) differentiation (Lopez \& Matschke, 2012) and (e) packaging (Chaya, Pacoud, Ng, Fenton \& Hort, 2015; Sester, Dacremont, Deroy \& Valentin, 2013; Venter, Van der Merwe, De Beer, Kempen \& Bosman, 2011).

In terms of the topic of this paper, the packaging category is vital. As the analysis by Aday and Yener (2014) reveals, the most important factors that influence young people when purchasing are packaging and label. Packaging and its originality can be a source of competitive advantage, as described in the case study of Heineken (Kotler et al., 2005). The influence of packaging on consumers is also mentioned by Sester et al. (2013). Both authors state that the packaging of individual types of beer strongly influences the emotional reactions of respondents and their association with them. 
Whilst Chaya et al. (2015) claimed that the product packaging does not reflect the sensory attributes of the beer it contains, they also stated that beer is an emotive product in which the brand plays a key role. In this regard, the packaging of the brand is usually connected with the brand (Chaya et al., 2015). In their early study, Allison and Uhl (1964) likewise found that branding, among the other purposes that the packaging is used for, can increase consumer loyalty toward that brands that consumers have not been able to recognize under blind conditions. These findings are well known among the professionals, although they are not alone in this. Similar findings are also provided by other authors, such as Donoghue, Jackson, Koop, and Heuven (2012), Sester et al. (2013), and Barnett et al. (2016).

Barnett et al. (2016) also proved that, in terms of glass bottles and aluminum cans, the packaging can affect consumers' perceived taste of the beer. This is important because, for Czech consumers, beer packaging plays an important role in the buying process (Foret \& Procházka, 2012). With Belgian consumers, the most important factors influencing purchasing behavior are the taste, type, and color of the beer (Poelmans \& Rousseau, 2017). For Czech consumers the packaging appears to be the second most important factor after taste (Foret \& Procházka, 2012) or after the brand (Horská, Ürgeová \& Prokeinová, 2011).

Following an overview of the current level of knowledge in the field and as per the questions set out at the beginning of this paper, the following research questions were formulated: (1) Will consumers be able to recognize the packaging material offered for the beer poured?; (2) What are the reasons given by consumers for why they prefer some types of packaging materials?; and (3) Will consumers be able to discern any differences in the taste of beer poured from different packaging materials?

\section{METHODS}

\subsection{Preliminary research}

As the literature review shows, there is a lack of reliable information related to the issue of Czech beer consumer behavior. Therefore, along with the authors' rush to understand the attitudes and preferences of Czech consumers, there was a need to conduct preliminary research. To be able to evaluate the contemporary situation on the Czech beer market from the consumer point of view, a short survey was conducted. A questionnaire, containing 21 closed and semiclosed questions, focused on four main consumer behavior issues: (a) the significance of packaging material within the buying process; (b) consumer opinion on how they can recognize the packaging material in a blind test; (c) environmental awareness of consumers and its influence on the packaging preference; and (d) the related gender differences.

The questionnaire prepared using the computer assisted web interviewing (CAWI) method (Rogers, Sharp \& Preece, 2002) was then randomly distributed to a sample of Czech beer consumers. The sample selection had only two limitations. Because of the legal restrictions, only respondents older than 18 were asked to participate. No upper age limit was set. The second limitation was connected to the obligatory previous experience of beer consumption, with the experience of buying packaged beers on a regular or semi-regular basis. Considering the information needs, as well as the limitation of the chosen research method, a total of 432 questionnaires were distributed via social sites using the snowball sampling method (Noy, 2008).

\subsection{Experiment}

Data from the questionnaire survey revealed the general behavior of the population on the packaged beer market. An experiment was conducted to verify the actual consumer behavior regarding the different beer packaging material and its influence on beer taste perception. Since the experiment was intended to answer the re- 
search questions related to an alcoholic beverage (beer), a controlled laboratory experiment that runs in a pre-engineered environment (Kozel, Mynářová \& Svobodová, 2011) was chosen.

As part of the attempt to verify actual consumer behavior with regard to various packaging materials used for beer, the goal was to determine whether the packaging could affect the subjectively perceived taste of the sample served. This could be easily verified in the experiment, in which the consumer should subjectively evaluate the sample of beer poured from a particular package in the same way, whether or not it is known from which package the beer is poured. If there is a statistically significant difference in the evaluation of the sample, it can be assumed that the packaging material influenced the consume's subjective perception of the taste of the sample.

\subsubsection{Experiment research assumptions}

The research assumptions were determined to verify the assumptions and goals of the experiment. To be able to respond to these, the research assumptions were operationalized. Operationalization helped to transform slightly fuzzy research assumptions into the strictly defining variables used as quantitatively measurable factors. Overall, two research assumptions and their related operationalization were set, as shown below:

$\mathbf{R A}_{\mathbf{1}}$ : In the tasting without information trial, the respondents will not be able to correctly identify the original packaging for all three beer samples.

Operationalization of $R A_{1}$ : The research assumptions will be confirmed if the observed probability of guessing all three samples for tasting without information is higher than the hypothetical probability of 0.167 and $16.7 \%$, respectively. The expression of the hypothetical probability of the correct assignment is provided in the equation below (1), where for the first sample, the respondent chooses from all three materials. When the respondent gives an answer concerning one of the samples, there are only two options to choose from. Finally, the respondent identifies the last packaging material.

$p=\frac{1}{(3 \times 2 \times 1)}=\frac{1}{6}=0.167$ respectively $16.7 \%$

$\mathbf{R A}_{\mathbf{2}}$ : There will be a statistically significant difference between the average results of sample tasting with information and with no information provided.

Operationalization of $R A_{2}$ : The research assumptions will be confirmed if the difference between the average results of sample tasting with information and with no information provided is statistically significant (t-test: $p \leq 0,5$ ).

\subsubsection{Research sample selection and beer sample}

The research experiment respondents were selected intentionally. Intentional selection is characterized in that the sample is not randomly chosen (Chraska, 2016). The reason for choosing this method was because only one group - university students aged 20 to 25 - were crucial for the research. The respondents also had to have experience of all three primary packaging materials of packaged beer. This experience means that students have already consumed beer from these three types of the packaging material.

The traditional Pilsner-type beer was chosen as the beer to be used in the experiment. This was a light $10^{\circ}$ beer with an alcohol content of $4.1 \%$, made by the Czech Pivovary Staropramen, LLC brewery and sold under the "Braník" brand name. The reason for choosing this beer was simple, as it is offered in all the necessary packaging materials.

\subsubsection{Research experiment design}

The research experiment was inspired by the paper published by Almenberg and Dreber (2011), in which they designed an experiment that examines how knowledge about the price of a product, and the time at which the information is received, affects how the product is 
experienced. Although the experiment was originally used for wine testing, it was adapted in this case to measure beer consumption behavior. The experiment was only slightly modified for the research.

The process of the experiment, shown in Figure 1, was as follows: The experiment took the form of guided tasting and was divided into two phases. In the first phase, the respondents had no information about the sample or its original packaging material. Conversely, in the second phase, the respondents had visual information about the packaging material the beer was poured from. In both cases, samples from individual packaging materials (glass/plastic bottle or aluminum can) were poured into a clean 0.3-liter glass, the sample itself equaling approximately 0.1 liters. All the respondents tasted the beer from different types of material in each of the three samples. Each sample was marked A, $B$, and $C$ for clarity. The respondents tasted the samples individually in both phases to avoid disturbing and influencing each other.

During the individual tastings, the respondents could compare samples among themselves. Subsequently, they assigned one of the three packaging materials to each sample and then evaluated the subjective taste of each sample. This evaluation was conducted using pre-printed forms, which were prepared for the respondents before the tasting began. To assess the subjectively perceived taste, a 10-point scale from 1 to 10 was prepared for each sample, with number 1 representing the worst and number 10 representing the best subjectively perceived taste.

After a thirty-minute break following the first phase of beer tasting, the second phase of the experiment started, which was similar to the first but with the difference that the respondents saw the original packaging behind each of the samples. They did not have to guess the packaging material, so in the evaluation, they focused only on their subjective evaluation of the taste. This was done on the same scale as in the previous phase. The experiment was con- cluded with personal interviews, in which the respondents stated their reasons for choosing the packaging material.

FIGURE 1: Experiment process diagram

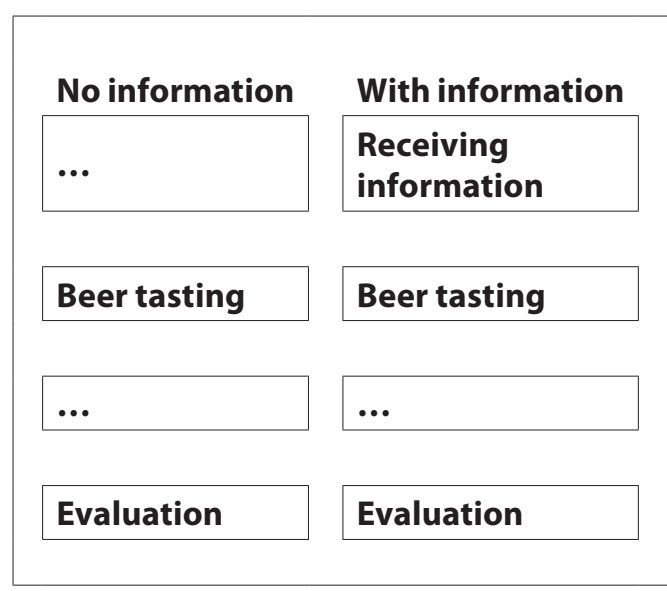

Source: Created by the authors based on Almenberg \& Dreber (2011)

\subsubsection{Research experiment design}

Since beer is a product that is subject to rapid oxidation and other negative external effects, every effort was made to avoid misrepresenting the results. Not only was the same brand of beer used, but it was also ensured that all the samples were served at the same temperature. All the bottled beers were taken directly from the cooling device before being poured into the universal anonymized glasses. Nevertheless, the research has at least one major limitation.

Despite all efforts, it cannot be guaranteed that the tested samples had a similar production date. In the Czech Republic, this information is not indicated on packaged beers. For this reason, the beers were selected according to the best before date. Unfortunately, there was a one-day difference for the beer packaged in a plastic bottle. While the beer in glass bottles and aluminum cans had the same best before date of 16 April 2019, the plastic bottle was marked best before 15 April 2019. 


\section{RESULTS}

\subsection{Preliminary research}

Of the 432 questionnaires sent out, only 220 responses could be used for further processing. This was due to the incomplete answers and discrepancies with the sample selection criteria (nationality, age limit, etc.). Of the 220 respondents, 111 were men and 109 were women. In terms of age, the group had a relatively equal distribution, with the individual age groups represented as follows: 18-25 years old (20.91\%), 25-35 years old (21.36\%), 35-45 years old (19.1\%), 45-55 (20.45\%), and 55 and older (18.18\%). In terms of education, the sample was divided as follows: no or basic education (1.36\%), upper and post-secondary education (67.73\%), tertiary education (30.91\%). Finally, according to their economic activity, the respondents were distributed as follows: students (18.18\%), employed 63.18\%, unemployed (0.45\%), entrepreneurs (8.18\%), pensioners (8.64\%), and on maternity leave (1.36\%).

As a result of the preliminary research questionnaire, data describing the so-called "typical Czech consumer of bottled (canned) beer" has been obtained. Typical Czech consumers buy packaged beer because of the convenience, that is, they can take it with them anywhere (58\%). They mostly buy packaged beer once a month. The main factors influencing their decision on which beer to choose are: (1) taste, (2) brand, (3) price, and (4) packaging material. Glass bottle was the packaging material most preferred by the vast majority of consumers (74\%). The three main reasons why consumers prefer this type of packaging are as follows: (1) habit, (2) price, and (3) environmental impact. Consumers are also convinced that the packaging material has an impact on the taste of the beer (68\%). In this respect, $80 \%$ of respondents preferred the glass bottle over other types of packaging because of the better taste of the beer. On the other hand, $68 \%$ of respondents think that they would be unable to recognize any possible taste difference in a blind test.

\subsection{Experimental research}

\subsubsection{With no information}

The guided tasting was first initiated in the phase where the respondent had no information about the sample. In the first step of this phase, each respondent was asked to guess the packaging material from which the sample was poured. In the second step, each sample was then evaluated for its taste. The results showing the guesses on which packaging material has been used are shown in Table 1.

The table below (Table 1) clearly shows, respectively, an absolute frequency of the respondents' answers and their guesses on the packaging material from which the tasted beer had been poured. The boxes marked blue represent the correct guesses of the original packaging material. The percentage of successful guesses is evident in the last column. Only five respondents correctly recognized it, which is the least correct

TABLE 1: Tasting with no information provided: guessing the packaging material $(n=30)$

\begin{tabular}{|c|c|c|c|c|}
\hline \multirow{2}{*}{$\begin{array}{l}\text { Packaging from } \\
\text { which the beer } \\
\text { was poured } \\
\text { (correct answer) }\end{array}$} & \multicolumn{3}{|c|}{ Respondents answers } & \multirow{2}{*}{$\begin{array}{l}\text { Percentage } \\
\text { success rate }\end{array}$} \\
\hline & Glass bottle & Aluminum can & Plastic bottle & \\
\hline Glass bottle & 9 & 10 & 11 & $30 \%$ \\
\hline Aluminum can & 8 & 9 & 13 & $30 \%$ \\
\hline Plastic bottle & 13 & 12 & 5 & $17 \%$ \\
\hline Checksum & 30 & 30 & 30 & \\
\hline
\end{tabular}

Source: Authors 
answer of all. At the same time, most respondents incorrectly marked the beer poured from a glass bottle as that poured from plastic.

The significance of this finding is enhanced by the claims of the respondents who, in their interviews, described beer from plastic packaging as the worst in terms of taste. These findings contradict the generally accepted assumptions about the poorer taste of beer distributed in a plastic bottle including the previously mentioned anecdotal evidence.

In total, only $10 \%$ of all the participants were able to respond correctly, which is even lower than the hypothetical probability according to the above calculation. In other words, this means that the respondents had not been able to accurately identify the original packaging for all three beer samples while tasting it with no information about the packaging provided. Thus, according to the criteria set within the operationalization, the first research assumption $(\mathrm{RA}$, ) has been verified.

\subsubsection{With information}

In the second phase of the experiment, the respondents only evaluated the taste of the beer. While in the first phase, they had no information about the beer, in the second they knew which packaging the beer was poured from. The statistically adjusted results of both measurements are shown in Table 2. At first sight, there are significant differences in some of the packaging materials.

Surprisingly, in the first phase, the respondents rated the beer poured from a plastic bottle as the best (average rating of 6.8 points). The beer poured from a can was placed on the opposite side of the scale, with an average taste rating of 5.2 points. The beer poured from a glass bottle achieved a rating of almost 5.8 points. The calculated median, which divides the values into two halves, also supports the distribution according to the average score.

Related to the above results, the respondents' statements from the interview are quite different. In absolute terms, 14 respondents claimed that they did not like beer from a plastic bottle. Overall, 24 respondents did not like plastic packaging for various reasons. On the other hand, the most popular material for bottled beer was glass. Glass was preferred by 26 respondents. Of these, 18 respondents preferred it because of its better effect on the taste of the beer.

The second part of the experiment yielded different results. Once the respondents knew the kind of packaging that the tasted beer was poured from, their taste evaluation changed. As may be expected, they liked the bottled beer the most. Compared to the others, this sample had the highest rating with an average score of 7.667 points, whereas the most frequently appearing value (mode) was 9 points. The beer poured from a can ranked second (average rating 4.9 points), with the beer poured from a plastic bottle in third place (average rating 4.6 points).

To verify the research assumption $\mathrm{RA}_{2^{\prime}}$ values from both phases of the experiment were subjected to statistical measurements. The paired Student's t-test was used to measure the statistical significance of the difference between

TABLE 2: Statistical values in samples tasting $(n=30)$

\begin{tabular}{|l|c|c|c|c|c|c|}
\hline Tasting & \multicolumn{3}{|c|}{ No information } & \multicolumn{3}{c|}{ With information } \\
\hline Packaging & $\begin{array}{c}\text { Glass } \\
\text { bottle }\end{array}$ & $\begin{array}{c}\text { Aluminum } \\
\text { can }\end{array}$ & $\begin{array}{c}\text { Plastic } \\
\text { bottle }\end{array}$ & $\begin{array}{c}\text { Glass } \\
\text { bottle }\end{array}$ & $\begin{array}{c}\text { Aluminum } \\
\text { can }\end{array}$ & $\begin{array}{c}\text { Plastic } \\
\text { bottle }\end{array}$ \\
\hline Mean & 5.833 & 5.200 & 6.800 & 7.667 & 4.900 & 4.633 \\
\hline Median & $\mathbf{6}$ & $\mathbf{4 , 5}$ & $\mathbf{7}$ & $\mathbf{8}$ & $\mathbf{4 , 5}$ & $\mathbf{4 , 5}$ \\
\hline Modus & 7 & 2 & 8 & 9 & 4 & 5 \\
\hline
\end{tabular}

Source: Authors 


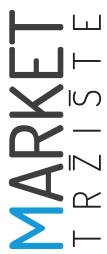

the results in the first and second phases of the experiment. Undeniable differences were measured in the case of beer poured from the plastic and glass bottles ( $t$-test: $p<0,001)$. However, while the results from the second phase were worse in the case of the plastic bottle, in the case of the glass bottle the average rating in the second phase improved. A statistically insignificant difference was then measured between the evaluation results for the beer poured from a can. The measured $p$-value was 0.568 at a significance level of $5 \%$.

Although the second research assumption $\left(R_{2} A_{2}\right)$ claimed that there would be a statistically significant difference in both the ratings of all samples, the assumption could not be confirmed. On the other hand, in the case of glass and plastic bottles, the differences were significant. Related to these facts, it is possible to conclude the significant influence of glass and plastic packaging of beer on consumers' preferences and their perceived taste of the beer. That is to say, if the respondents did not know what packaging material the sample came from, then they would like the beer coming from the plastic packaging the most. On the contrary, if they knew what packaging the beer had been poured from, they would prefer the beer from a glass bottle while rating the taste of the beer poured from plastic as the worst.

These results confirm the references stated above in casual conversation and also correspond to the respondents' answers to the short after-experiment interview. The interviews showed that, if the respondents can choose from the above-mentioned packaged beers, 26 participants would choose glass bottled beer first and 24 would choose a plastic bottle last.

\section{DISCUSSION AND CONCLUSION}

As the results of the questionnaire survey show, more men than women believe that they can recognize the packaging material that the beer is poured from. However, that claim was not confirmed by this experiment, in which no statistical significance was found between sex and the ability to recognize the packaging material of the tasted beer.

According to the result, the participants in the experiment most often recognized glass and metal packaging. However, only less than a third of all the participants in the experiment were able to identify the correct packaging, with the guessing success rate of just 30\%. Surprisingly, the respondents guessed the plastic packaging the least often. This contradicts the results of the survey, in which more than a half of the respondents described the beer from plastic bottles as inferior, saying that it has the worst taste. Only 5 out of 30 respondents recognized beer from plastic packaging. Also, 13 respondents claimed that the sample tasted like beer poured from a glass bottle - the packaging that the respondents stated as the one from which the taste of beer is the best.

However, this success rate of packaging material recognition was related only to individual packaging materials. Considering the situation where the correct identification of all three packaging materials was required, the success rate was far lower. In absolute figures, only three respondents correctly assigned the packaging material to all three samples. According to the results obtained, it can be stated that if the respondents did not have information about individual samples while tasting, then they were not able to correctly assign the beer to the three types of packaging material.

In the first part of the paper, three research questions were set. Through the research findings, they were answered within the previous text. The answers can be summarized as follows: (1) Consumers were not able to correctly recognize the packaging material the beer was poured from. (2) Consumers mostly prefer beer in a glass bottle because of their habit, environmental impact, and because of its subjectively perceived better taste. On the contrary, because of its negative environmental impact and the subjectively perceived worse taste, plastic bot- 
tle is the least attractive packaging. (3) In both phases of the experiment, the participants were able to discern the differences between the samples, whereas the subjectively perceived differences were statistically significant.

The research has some limitations, which can be divided into two parts. The first is related to the preliminary research, the second to the experiment. The main limitation of the preliminary research lies in its regionality because the research was only conducted in the Czech Republic. Although some beer-related consumer behavior traits are the same for every consumer (Donoghue et al., 2012), Czech beer consumers can differ in their preferences (Rumánková et al., 2019). Therefore, it would be quite difficult to generalize the results. The total sample size $(n=220)$ and the sampling method also appear to be limited, thus creating further generalization.

For further research, it would be valuable to measure the consumer behavior of beer lovers within different countries of the world. Although such research already exists (e.g. Foret \& Procházka, 2012; Aquilani et al., 2015; or Barnett et al., 2016), data collection methodologies differ. Using a uniform data collection method would allow distinguishing the variations in consumer behavior considering their country of origin.

In the second part, the number of participants appears to be adequate. Nevertheless, the main limitation lies in the experiment participants themselves because they were college stu- dents. Thus, the results of the experiment provide a valuable view of this group's consumer behavior, but again, they cannot be generalized. Therefore, future research should focus on other consumer groups and other countries.

When it comes to the experiment, it must be emphasized that the participants' overconfidence bias (Sutherland, 1992) was not considered in the statistical evaluation of the experiment. It can be argued that, regardless of the subject studied, people tend to overestimate their analytical skills (Greening \& Chandler, 1997). To increase the accuracy of the experimental data, it would be appropriate to include the given deviation in the statistical evaluation (Camerer \& Lovallo, 1999). However, the problem lies in the individuality of the participants, so it would be appropriate in further research to combine the procedures into an experiment that could reveal the degree of overconfidence.

Brewery globalization and the growing importance of local micro-breweries induce the demand for specific information on the consumption patterns of beer drinkers across the nations. To be able to provide such information, future research should overcome the previously mentioned limitations. Hence, further emphasis should be placed on research with a larger sample of beer consumers from different nations. Also, the possibility of using a sample of beer for testing from different manufacturers should be considered. 


\section{References}

1. Aday, M. S., \& Yener, U. (2014). Understanding the buying behavior of young consumers regarding packaging attributes and labels. International Journal of Consumer Studies, 38(4), 385-393.

2. Allison, R. I., \& Uhl, K. P. (1964). Influence of beer brand identification on taste perception. Journal of Marketing Research, 1(3), 36-39.

3. Almenberg, J., \& Dreber, A. (2011). When does the price affect the taste? Results from a wine experiment. Journal of Wine Economics, 6(1), 111-121.

4. Andrés-Iglesias, C., Nešpor, J., Karabín, M., Montero, O., Blanco, C. A., \& Dostálek, P. (2016). Comparison of carbonyl profiles from Czech and Spanish lagers: Traditional and modern technology. LWT - Food Science and Technology, 66, 390-397.

5. Aquilani, B., Laureti, T., Poponi, S., \& Secondi, L. (2015). Beer choice and consumption determinants when craft beers are tasted: An exploratory study of consumer preferences. Food Quality and Preference, 41, 214-224.

6. Barnett, A., Velasco, C., \& Spence, C. (2016). Bottled vs. canned beer: Do they really taste different? Beverages, 2(4), 25-36.

7. Baxter, E. D., Hornsey, I. S., \& Hughes, P. S. (2001). Beer: Quality, safety and nutritional aspects. London: Royal Society of Chemistry.

8. Brager, D., \& Greco, J. (2011). Millennials Redefine the Alcoholic Beverage Landscape. Nielsen Wire. Available at: http://www.nielsen.com/us/en/insights/news/2011/millennials-redefine-the-alcohol-beveragelandscape.html (accessed January $11^{\text {th }}, 2020$ ).

9. Bräker, A. B., \& Soellner, R. (2016). Alcohol drinking cultures of European adolescents. The European Journal of Public Health, 26(4), 581-586.

10. Bronnenberg, B. J., Dubé, J-P. H., \& Gentzkow, M. (2012). The evolution of brand preferences: Evidence from consumer migration. American Economic Review, 102(6), 2472-2508.

11. Burns, C. S., Heyerick, A., De Keukeleire, D., \& Forbes, M. D. (2001). Mechanism for formation of the lightstruck flavor in beer revealed by time-resolved electron paramagnetic resonance. Chemistry - A European Journal, 7(21), 4553-4561.

12. Camerer, C., \& Lovallo, D. (1999). Overconfidence and excess entry: An experimental approach. American Economic Review, 89(1), 306-318.

13. Castiglione, C., Grochová, L., Infante, D., \& Smirnova, J. (2011). The demand for beer in the presence of past consumption and advertising in the Czech Republic. Agricultural Economics, 57(12), 589-599.

14. Chaya, C., Pacoud, J., Ng, M., Fenton, A., \& Hort, J. (2015). Measuring the emotional response to beer and the relative impact of sensory and packaging cues. Journal of the American Society of Brewing Chemists, 73(1), 49-60.

15. Chraska, M. (2016). Metody pedagogického výzkumu: Základy kvantitativního výzkumu. Prague: Grada Publishing.

16. Donoghue, C., Jackson, G., Koop, J. H., \& Heuven, A. J. M. (2012). The environmental performance of the European brewing sector. Brussels: European Union.

17. Foret, M., \& Procházka, P. (2012). Behavior and decision making of Czech consumers when buying beverages. Agricultural Economics, 52(7), 341-346.

18. Galizzi, M. M., \& Garavaglia, C. (2012). Probably not the best lager in the world: Effect of brands on consumers' preferences in a beer tasting experiment. Liuc papers - Serie Economia e Impresa, 254(65), 1-22.

19. Greening, L., \& Chandler, C. C. (1997). Why It Can't Happen to Me: The Base Rate Matters, But Overestimating Skill Leads to Underestimating Risk 1. Journal of Applied Social Psychology, 27(9), 760-780. 
20. Horská, E., Ürgeová, J., \& Prokeinová, R. (2011). Consumers' food choice and quality perception: Comparative analysis of selected Central European countries. Agricultural Economics, 57(10), 493-499.

21. Kleban, J., \& Nickerson, I. (2012). To brew, or not to brew - That is the question: An analysis of competitive forces in the craft brew industry. Journal of the International Academy for Case Studies, 18(3), 59-82.

22. Kotíková, H. (2013). Nové trendy v nabídce cestovního ruchu. Prague: Grada.

23. Kotler, P., Armstrong, G., Saunders, J., \& Wong, V. (2005). Principles of Marketing. $4^{\text {th }}$ European ed. London: Prentice Hall.

24. Kozák, V. (2013). Analysis of Reasons for Beer Consumption Drop in the Czech Republic. E+ M Ekonomie a Management, 16(3), 130-141.

25. Kozel, R., Mynářová, L., \& Svobodová, H. (2011). Moderní metody a techniky marketingového výzkumu. Prague: Grada.

26. Kuchel, L., Brody, A. L., \& Wicker, L. (2006). Oxygen and its reactions in beer. Packaging Technology and Science: An International Journal, 19(1), 25-32.

27. Kuo, M., Wechsler, H., Greenberg, P., \& Lee, H. (2003). The marketing of alcohol to college students: the role of low prices and special promotions. American journal of preventive medicine, 25(3), 204-211.

28. Lintonen, T. P., \& Konu, A. I. (2003). Adolescent alcohol beverage type choices reflect their substance use patterns and attitudes. Journal of youth and adolescence, 32(4), 279-289.

29. Lopez, R. A., \& Matschke, X. (2012). Home bias in US beer consumption. Pacific Economic Review, 17(4), 525-534.

30. Lorencová, E., Salek, R. N., Černošková, I., \& Buňka, F. (2019). Evaluation of force-carbonated Czech-type lager beer quality during storage in relation to the applied type of packaging. Food Control, 106, 106706.

31. Noy, C. (2008). Sampling knowledge: The hermeneutics of snowball sampling in qualitative research. International Journal of social research methodology, 11(4), 327-344.

32. Petr, M. (2018). Pivo v plechu zvítězilo nad plastem, sklo ale stále dominuje. Available at: https:// www.lidovky.cz/relax/pivo-a-pivovary/pivo-v-plechu-zvitezilo-nad-plastem-sklo-ale-stale-dominuje.A180608_134216_firmy-trhy_pkk (accessed December 15 $5^{\text {th }}, 2019$ ).

33. Poelmans, E., \& Rousseau, S. (2017). Beer and organic labels: Do Belgian consumers care? Sustainability, 9(9), 1509.

34. Rogers, Y., Sharp, H., \& Preece, J. (2002). Interaction Design: Beyond Human-Computer Interaction. New York, NY: Jon Wiley \& Sons.

35. Rojas, C., \& Shi, T. (2011). Tax incidence when quality matters: Evidence from the beer market. Journal of Agricultural \& Food Industrial Organization, 9(1), 1-33.

36. Rumánková, L., Šánová, P., \& Kolář, P. (2019). Beer Consumption in the Czech Republic and its Determinants. Scientia Agriculturae Bohemica, 50(1), 64-69.

37. Sester, C., Dacremont, C., Deroy, O., \& Valentin, D. (2013). Investigating consumers' representations of beers through a free association task: A comparison between packaging and blind conditions. Food Quality and Preference, 28(2), 475-483.

38. Smith, S., Farrish, J., McCarroll, M., \& Huseman, E. (2017). Examining the craft brew industry: Identifying research needs. International Journal of Hospitality Beverage Management, 1(1), 3-15.

39. Sohrabvandi, S., Mortazavian, A. M., \& Rezaei, K. (2012). Health-related aspects of beer: a review. International Journal of Food Properties, 15(2), 350-373.

40. Spence, C., \& Piqueras-Fiszman, B. (2012). The multisensory packaging of beverages. In: M. Kontominas (ed.), Food Packaging: Procedures, Management, and Trends (pp. 187-234). Hauppauge, NY: Nova Science Publishers. 
41. Sutherland, S. (1992). Irrationality: The enemy within. London: Constable and Company.

42. Swinnen, J. F. M. (ed.) (2011). The economics of beer. Oxford: Oxford University Press.

43. Vacl, J. (2018). The Impact of Microbreweries on Travel in the Czech Republic. Kvasný Průmysl, 64(2), 76-87.

44. Van Herck, K., Swinnen, J. F., \& Deconinck, K. (2012). How the east was won: Supply chain restructuring in the Eastern European beer market. German Journal of Agricultural Economics, 61, 213-222.

45. Vaughan, A., O'Sullivan, T., \& Sinderen, D. (2005). Enhancing the Microbiological Stability of Malt and Beer - A Review. Journal of the Institute of Brewing, 111(4), 355-371.

46. Velasco, C., Woods, A. T., Petit, O., Cheok, A. D., \& Spence, C. (2016). Crossmodal correspondences between taste and shape, and their implications for product packaging: A review. Food Quality and Preference, 52, 17-26.

47. Venter, K., Van der Merwe, D., De Beer, H., Kempen, E., \& Bosman, M. (2011). Consumers' perceptions of food packaging: an exploratory investigation in Potchefstroom, South Africa. International Journal of Consumer Studies, 35(3), 273-281.

48. Vesely, P., Lusk, L., Basarova, G., Seabrooks, J., \& Ryder, D. (2003). Analysis of Aldehydes in Beer Using Solid-Phase Microextraction with On-Fiber Derivatization and Gas Chromatography/Mass Spectrometry. Journal of Agricultural and Food Chemistry, 51(24), 6941-6944. 